\title{
Resilience of athletes: A systematic review based on a citation network
}

\author{
analysis
}

\section{Resiliencia de los atletas: Una revisión sistemática basada en un análisis de redes de citas}

\section{Resiliência de atletas: uma revisão sistemática com base na análise da rede de citação}

\author{
Bicalho, C.C.F.1, Melo, G.F.2, Noce, F.3 \\ ${ }_{1}$ Universidade do Estado de Minas Gerais;2Universidade Católica de Brasília 3 Universidade Federal de \\ Minas Gerais
}

\begin{abstract}
The aims of the study are to understand indicators and the scope of theoretical models adopted to describe athletes' resilience, as well as to analyze their impact on investigations about this resilience. A search for original academic publications within a 10-year period was conducted in the PubMed / Medline, Web of Science, Taylor and Francis, Lilacs, Scopus, Human Kinects, and Science Direct databases. Articles were analyzed based on their methodological characteristics and citation network analysis. In total, 47 articles were identified, the most referenced of which was Fletcher and Sarkar (2012), followed by Galli and Vealey (2008). The Grounded Theory of Psychological Resilience and Optimal Sport Performance by Fletcher and Sarkar (2012) seems to best encompass the basic theoretical elementary aspects to better understand athletes' resilience. In conclusion, the sport resilience is an on-going dynamic process based on psychological individual characteristics and interactions the athlete with the environment.
\end{abstract}

Keywords: Resilient characteristics, Psychological training, Mental health, Psychological wellbeing, Positive adaptation.

\section{RESUMEN}

Los objetivos del estudio son buscar los indicadores y el alcance de los modelos teóricos adoptados para describir la resiliencia de los atletas y analizar el impacto en las investigaciones sobre la resiliencia. Se realizaron búsquedas en publicaciones académicas originales durante un período de 10 años en las bases de datos PubMed / Medline, Web of Science, Taylor and Francis, Lilacs, Scopus, Human Kinects y Science Direct. Los artículos fueron analizados en función de sus características metodológicas y análisis de la red de citas. En total, se identificaron 47 artículos, de los cuales los más mencionados fueron Fletcher y Sarkar (2012) y Galli y Vealey (2008). La teoría fundamentada de la resistencia psicológica y el rendimiento deportivo ideal, Fletcher y Sarkar (2012) parece cubrir mejor los aspectos elementales teóricos básicos para comprender la resistencia deportiva. En conclusión, la resiliencia deportiva es un proceso dinámico continuo, basado en las características psicológicas individuales y las interacciones del atleta con el medio ambiente.

Palabras clave: Características resilientes, entrenamiento psicológico, salud mental, bienestar psicológico, adaptación positiva. 


\section{Resilience of athletes}

\section{RESUMO}

Os objetivos do estudo são buscar os indicadores e o escopo dos modelos teóricos adotados para descrever a resiliência dos atletas e analisar o impacto nas investigações sobre resiliência. Publicações acadêmicas originais foram buscadas dentro de um período de 10 anos nas bases de dados PubMed / Medline, Web of Science, Taylor e Francis, Lilacs, Scopus, Human Kinects e Science Direct. Os artigos foram analisados com base em suas características metodológicas e análise da rede de citações. No total, foram identificados 47 artigos, dos quais os mais referenciados foram Fletcher e Sarkar (2012) e Galli e Vealey (2008). A Teoria Fundamentada da Resiliência Psicológica e do Desempenho Esportivo Ideal, Fletcher e Sarkar (2012) parece melhor abranger os aspectos elementares teóricos básicos para entender a resiliência esportiva. Concluindo, a resiliência esportiva é um processo dinâmico contínuo, baseado nas características psicológicas individuais e nas interações do atleta com o meio ambiente.

Palavras chave: Características resilientes, Treinamento psicológico, Saúde mental, Bem-estar psicológico, Adaptação positiva.

\section{INTRODUCTION}

According to the concept by Richardson et al. (1990), resilience is a psychological reintegration process based on the ability to learn new skills from stressful experiences and from the perspective of enhancing skills to cope with further stressful events in life. This construct is culturally and contextually dependent on socio-environmental factors (Luthar\&Cicchetti, 2000, Luthar, Cicchetti\& Becker, 2000, Morgan, Fletcher \& Sarkar, 2013) or on events faced throughout life. According to Masten (2001), stressful community events become active agents to create resilient individuals.

Athletes seem to experience the nature of their stress differently from non-athletes (Wagstaff et al., 2016); moreover, former athletes are often more resilient, have better general health, lesser anxiety, and deal with emotional aspects better than non-athletes (Barley et al., 2012). Based on Fletcher and Sarkar (2012), athletes are more prepared to deal with stressor events, and this factor opens space for resilience development. According to these authors, athletes face difficult situations in order to improve their performance, different from individuals who need to show resilient skills in order to maintain normal functional levels after experiencing stressful situations.

According to Pedro and Veloso (2018), athletes' resilience "unveils" personal skills that protect individuals from the negative effects of stressful events. These skills allow athletes to have better and easier adaptation to negative or stressful circumstances often experienced in environment/individual interaction events. Studies have shown that resilience can also contribute to athletes' psychological well-being and to reducing psychological distress (Hosseini \& Besharat,2010; Nezhad \& Besharat, 2010).

Some theoretical models have been elaborated to explain athletes' resilience skills, taking into account specificities of sports environments. Based on Galli and Vealey (2008), the process to become resilient is related to exposure to adversities and to the strong influence of difficult episodes in the lives of athletes. Adversities are herein understood as stressor injuries, burnout, and career transitions that have the power to influence athletes' behavior. However, it is important to highlight that despite many unpleasant feelings and difficult circumstances experienced by athletes, they benefit from coping with their adversities.

According to the Conceptual Model of Resilience by Galli and Vealey (2008), resilience is the consequence of agitation states caused by athletes' exposure to stressors managed by sociocultural influences and personal resources. Based on this model, the reintegration of athletes after an adverse event leads to positive responses and contributes to enhanced resilience skills; in other words, resilience goes beyond the athlete trait, it involves environmental influences, as well as inner adaptation processes. However, the authors do not explain how the reintegration process contributing to the development of resilience skills in athletes occurs in practice.

Later, Fletcher and Sarkar (2012) introduced the Grounded Theory of Psychological Resilience and Optimal Sport Performance, which states that resilience development depends on stressors, 


\section{Bicalho, C.C.F., Melo, G.F., \& Noce, F.}

cognitive evaluation, meta-cognition, and personality. It is composed of five main psychological protection factors linked to the potential negative effect of stressors, namely: positive personality, motivation, confidence, focus, and perceived social support, which influence the way the athletes face challenges and their meta-cognition. These processes make it easier to achieve responses that precede optimal sport performance. The ability of athletes to interpret their emotions and make effective decisions is a key element to achieve better results and athletes move on from what has happened and highly commit to tasks. This model appears to provide a complementary perspective and explains some gaps presented in previous studies

Observing the advances in the literature on resilience in athletes, the need arises to evaluate which of these theoretical structures guides the research. In high performance sports modalities athletes are subjected to physical and mental stress due to the demand for good physical performance in training sessions and for success in competitions. Actually, the most resilient athletes seem to be better prepared to overcome challenges and stress in the sports environment, a fact that increases their likelihood of remaining in the sports career (Cevadaet al., 2012; Hosseini \& Besharat, 2010). Studies have also shown that resilience is the key skill for athletes to be successful in sports (Holt \&Dunn, 2004; Hosseini \& Besharat, 2010; Meggs et al., 2016; Mills et al, 2012; Van Yperen, 2009). Gucciardi et al (2011), Sarkar and Fletcher (2013), Wagstaff et al. (2016) have advocated for in-depth knowledge about resilience in the sports context.

Some relevant questions should be answered, such as: What is the best way to understand the impact of resilience on athletes' performance if one takes into consideration all differences between the introduced theoretical models? Are these models truly guiding the field of resilience in athletes? How have these studies been conducted recently? Therefore, it is of great importance to investigate the main theoretical models used in sport resilience, and how these models have shaped subsequent citation structure, as shown in other studies (Gustafsson,Hancock, Cotê, 2014).

In order to clarify these questions, a systematic review study was conducted. The aims of this review are to understand the indicators and scope of the aforementioned theoretical models, to analyze the prominence and interconnectedness of athletes' resilience research and the frequency of review, and report the characteristics of studies in the citation network.

\section{METHODS}

\section{Search Strategy}

The first step of the citation analysis was to identify relevant articles. A search was performed in databases used in sport science research: PubMed/Medline, Web of Science, Taylor and Francis, Lilacs, Scopus, Human Kinects, and Science Direct databases between 2008 and 2018. In addition, hand searching of journals was performed, including: The Sport Psychologist, International Journal of Sport Psychology, International Journal of Sport \& Exercise Psychology, Journal of Applied Sport Psychology, Journal of Clinical Sport Psychology, Revista de Psicología del Deporte, and Cuadernos de Psicología del Deporte.

The search encompassed articles written in Portuguese, English and Spanish, based on the following prescriptors: resilience (resiliencia), athletes (atletas, desportistas), sport (esporte, deporte). These terms could be in the title, in the abstract, or in the keywords of the found articles. These words were combined using the connective "AND" for example: "Resilience AND Athletes"; "Resilience AND Athletes AND Sport".

Inclusion criteria were based on three factors: (a) written in English, Portuguese, or Spanish; (b) assessed resilience, or other interventions, in highperformance athletes; (c) published in an indexed database and peer reviewed journal between January 2008 and March 2018. The publication date of the first theoretical model focused on resilience in sportsnamely: the Conceptual Framework of Resilience by Galli and Vealey (2008) - and substantiated the 10year period established to select publications in this field. This period was considered sufficient to comply with the main aim of this review, understanding the indicators and scope of theoretical models on resilience in the sports context.

Exclusion criteria included (a) annals of and supplements on scientific events, (b) position statements, reviews, editorials, and instrumentvalidation articles, (c) articles based on samples 


\section{Resilience of athletes}

composed of non-athlete students, coaches, referees, physicians, and entrepreneurs, (d) articles investigating mental toughness, beliefs, selfconfidence, personality, and other related subjects, and (e) duplicated studies. Studies published in more than one of the assessed databases or that did not meet the default inclusion criteria were also excluded from the review (Figure 1). In total, 144 articles were selected (articles identified in the databases $n=125$, articles found in journals in this scientific field $n=19$ ). The second author of this article repeated the search ensure that no article suitable for inclusion in the review was missed. After applying the inclusion and exclusion criteria, the final sample comprised 47 publications. The procedures followed recommendations in the PRISMA protocol.

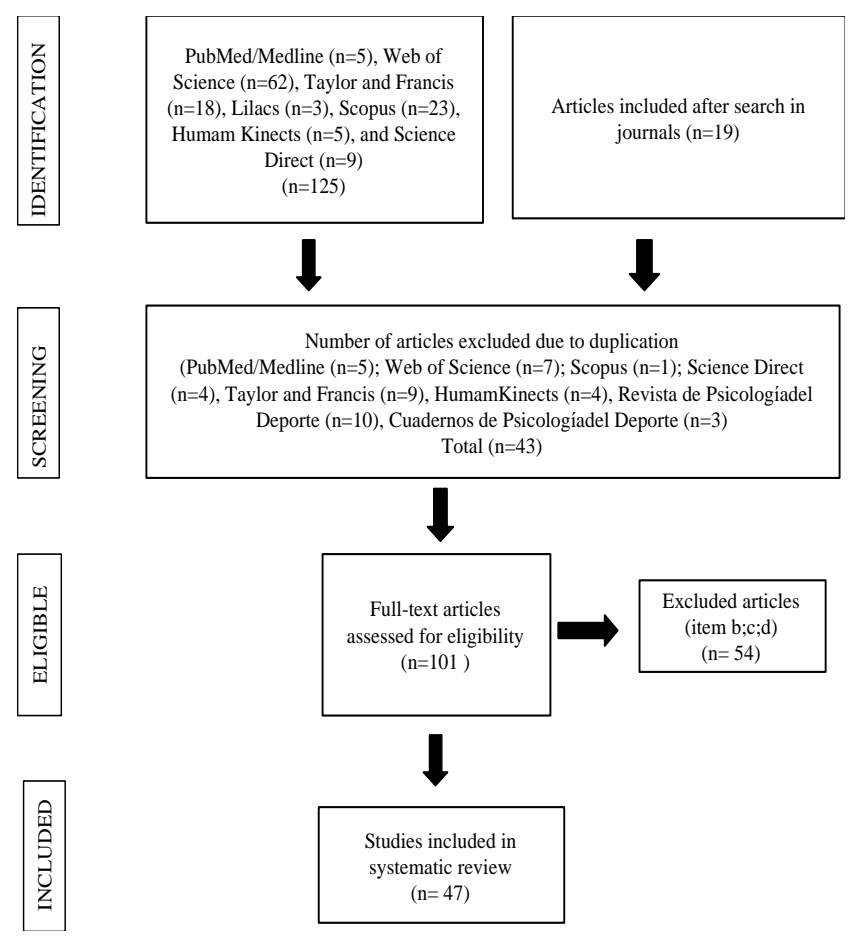

Figure 1: Procedure adopted to select articles on Athletes' resilience.

\section{Analysis}

The selected articles were organized and numbered in ascending order, based on publication year. The review was divided into three stages: the first followed the descriptive protocol by Sallis, Prochaska and Taylor (2000), which was used in other systematic reviews (Bicalho \& Costa, 2017; Goodger et al. 2007); In the second stage, the articles were labeled with a number - from one (1) to forty seven (47) - (these numbers were recorded in a spreadsheet to create a citation matrix); the third stage was based on identifying articles listed as a reference in each of the selected studies and listing them in the matrix (for example, Bruner et al., 2013; Gustafsson, Hancock, \&Cotê, 2014). In the case that article 1 had referenced articles 10, 20, and 30, number " 1 " would be written on line 1, below columns " $10 "$, " 20 ", and " 30 " (Gustafsson, Hancock, \&Cotê, 2014). A complete matrix of articles referenced by other authors was developed based on this procedure. Articles that had not been referenced by other authors were labeled with code " 0 ".

Quotation structures evaluated in the third stage were assessed in UCINET® 6 software (Borgatti, Everett \& Freeman, 2002), which analyzes the structures of relationships between network elements. The graphic representation package NETDraw 2.161 (Borgatti, 2002) of UCINET® 6 depicts the article matrix and allows visualization of the relationship between elements in the matrix. This software also provides centrality indices, which represent the number of times an article is quoted or quotes another article in the matrix. This process enables the objective comparison of articles.

Network analysis is mainly based on grade-centric scores, since they indicate the most central and influential role of elements in the network; therefore, the most commonly referenced articles in the publications composing the network would be centralized (Gustafsson, Hancock \&Cotê, 2014). Network density was calculated by dividing the number of existing relationships (RE) by the number of possible relationships, and by multiplying the result by $100(\mathrm{D}=\mathrm{RE} / \mathrm{RP} * 100)$, according to the protocol of Borgatti, Everett and Johnson (2013). Possible relationships were calculated (PR) by multiplying the total number of Nodes by the total number of Nodes subtracted from $1[\mathrm{PR}=\mathrm{NTN} *(\mathrm{NTN}-1)]$.

The nature of the study, which was addressed as qualitative, quantitative, and mixed, was also included in the analysis. New codes were inserted in the UCINET ${ }^{6} 6$ software in order to conduct this analysis: 


\section{Bicalho, C.C.F., Melo, G.F., \& Noce, F.}

"1" to codify the qualitative analysis, "2" the quantitative analysis, and "3" the mixed analysis (both qualitative and quantitative). The nature of the study was represented by the color of the Nodes: the blue Node corresponded to the qualitative studies, the red Node to the quantitative studies, and the yellow Node to the mixed studies.Procedimiento

\section{RESULTS}

General Findings

In total, 47 studies on athletes' resilience were selected. Table 1 is based on a descriptive analysis and presents information about the selected studies according to the characteristics of the evaluated athletes.

Table 1: Summary of the Sample based on Athletes' Characteristics in Resilience Studies

\begin{tabular}{|c|c|c|}
\hline Characteristic & Reference number & Sample k (\%) \\
\hline \multicolumn{3}{|l|}{ Sample Size } \\
\hline$\geq 25$ & $1,4,6,8,9,14,17,19,20,24,25,27,41,43,44$ & $15(31.91)$ \\
\hline $25-50$ & $5,10,11,13,21,22,32,34$ & $08(17.02)$ \\
\hline $50-100$ & $18,30,39,42,46$ & $05(10.63)$ \\
\hline $101-150$ & $2^{\#}, 3^{\#}, 28,40$ & $04(8.51)$ \\
\hline $151-200$ & $15,38,45,47$ & $04(8.51)$ \\
\hline $201-250$ & $7,12,23,29,37$ & $05(10.63)$ \\
\hline $251-300$ & -- & -- \\
\hline$>300$ & $16,26,31,33,35^{\#}, 36^{\#}$ & $06(12.76)$ \\
\hline \multicolumn{3}{|l|}{ Sex } \\
\hline Male & $9,14,15,22,34,44$ & $06(12.76)$ \\
\hline Female & $8,19,24,28,42$ & $05(10.63)$ \\
\hline Combined & $1,2,3,4,5,6,7,10,11,12,13,16,17,18,20,21,23,25,26,27,29,30,31,32,33,35,36,37,38,39,40,41,43,45,46,47$ & $36(76.59)$ \\
\hline \multicolumn{3}{|l|}{ Age, in years } \\
\hline $17-19$ & $11,13,15^{*}, 16,21 *, 25^{*}, 28,30,32 *, 35^{*}, 36^{*}, 38,41$ & $13(20.00)$ \\
\hline $20-23$ & $2^{\#}, 3^{\#}, 7,9^{*}, 15^{*}, 17,20,22,23,24,29,31,32^{*}, 33,35^{*}, 36^{*}, 37,40,47$ & $19(29.23)$ \\
\hline $24-27$ & $1,5,9 *, 10,15^{*}, 25 *, 32 *, 35^{*}, 36^{*}, 46$ & $10(15.38)$ \\
\hline$>27$ & $6,9^{*}, 12,15^{*}, 18,32^{*}, 35^{*}, 36^{*}$ & $08(12.30)$ \\
\hline Unidentified & $4,8,14,32 *, 43,44$ & $06(9.23)$ \\
\hline \multicolumn{3}{|c|}{ Sport Characteristic } \\
\hline Team & $8,9,13,14,18,28,42,47$ & $08(17.02)$ \\
\hline Individual & $4,11,17,19,20,21,24,27,34,35,36,39,40,41,43,44,46$ & $17(36.17)$ \\
\hline Combined & $1,2^{\#}, 3^{\#}, 5,6,7,10,12,15,16,22,23,25,26,29,30,31,32,33,37,38,45$ & $22(46.80)$ \\
\hline \multicolumn{3}{|l|}{ Design } \\
\hline Cross-sectional & $1,2,3,4,5,6,7,8,9,11,12,13,14,15,16,17,18,19,20,22,23,26,27,28,29,31,32,33,34,35,36,38,40,42,43,45,46,47$ & $38(80.85)$ \\
\hline Longitudinal & $10,21,24,25,30,37,39,41,44$ & $09(19.14)$ \\
\hline Quantitative & $2^{\#}, 3^{\#}, 5,7,11,12,13,15,16,18,22,23,26,27,28,29,30,31,32,33,34,35,36,37,38,39,40,42,45,46,47$ & $31(65.95)$ \\
\hline Mixed & 24,41 & $02(4.25)$ \\
\hline
\end{tabular}




\section{Resilience of athletes}

\begin{tabular}{|c|c|c|}
\hline \multicolumn{3}{|l|}{ Data Collection } \\
\hline CD-Risc 10 & 16 & $01(2.08)$ \\
\hline CD-Risc 25 & $2^{\#}, 3^{\#}, 13,15,18,22,23,32,40,42,47$ & $11(22.91)$ \\
\hline Resilience Scale & $5,11,12,27,28,29,37,39,45,46$ & $10(20.83)$ \\
\hline Resilience Scale for Adults & 35,36 & $02(4.16)$ \\
\hline Ego Resilience 89 Scale & 33 & $01(2.08)$ \\
\hline Academic Resilience Scale & 34 & $01(2.08)$ \\
\hline Psychological Resilience Scale for & 30,38 & $02(4.16)$ \\
\hline \multicolumn{3}{|l|}{ University Athletes } \\
\hline Resistance to Peer Influence Scale & 26 & $01(2.08)$ \\
\hline Post-traumatic growth inventory - PTGI & 7 & $01(2.08)$ \\
\hline Psychological Well-Being Scale & 31 & $01(2.08)$ \\
\hline Focus Group & $10^{*}$ & $01(2.08)$ \\
\hline Interview & $1,4,6,8,9,10^{*}, 14,19,20,43$ & $10(20.83)$ \\
\hline Autobiograp hy Analysis & 17 & $01(2.08)$ \\
\hline Therapy Intervention & $21,24,25,41,44$ & $05(10.41)$ \\
\hline \multicolumn{3}{|l|}{ Location } \\
\hline Europe & $6^{*}, 10,20,21,22,26,27,29,31,32,33,34 *, 37,39,42,45,46,47$ & $18(35.29)$ \\
\hline Oceania & $6^{*}, 17 * 19,34^{*}$ & $04(7.84)$ \\
\hline North America & $1,7,9,14,16,17 *, 18,24,25,43,44$ & $11(21.56)$ \\
\hline South America & $4,5,8,11,12,13,40$ & $07(13.72)$ \\
\hline Asia & $2^{\#}, 3^{\#}, 15,23,30,38,41$ & $07(13.72)$ \\
\hline Central America & - & -- \\
\hline Africa & $17 *, 35,36$ & $03(5.88)$ \\
\hline Unidentified & 28 & $01(1.96)$ \\
\hline \multicolumn{3}{|l|}{ Publication Year } \\
\hline $2008-2012$ & $1,2,3,4,5,6,7$ & $07(14.89)$ \\
\hline 2012- 2018 & $\begin{array}{l}8,9,10,11,12,13,14,15,16,17,18,19,20,21,22,23,24,25,26,27,28,29,30,31,32,33,34,35,36,37,38,39,40,41,42,4 \\
3,44,45,46,47\end{array}$ & $40(85.10)$ \\
\hline
\end{tabular}

Note. $\mathrm{K}=$ number of sampled populations. \#Studies presenting data of the same independent samples

Reference numbers of resilience studies: 1=Galli\&Vealey (2008); 2=Hosseini\&Besharat (2010); 3=Nezhad\&Besharat (2010); 4=Sanches\& Rubio (2011); 5=Cevada et al. (2012); 6=Fletcher \& Sarkar (2012); 7=Galli\& Reel (2012); 8=Fontes\&Brandão (2013); 9=Machida, Irwin \&Feltz (2013); 10= Morgan, Fletcher \& Sarkar (2013); 11=García, Vallarino\& Montero (2014); 12=Cardoso \&Sacomori (2014); 13=Belem, Caruzzo,Nascimento Junior et al (2014); 14=Morgan, Fletcher \& Sarkar (2015); 15= Boghrabadi, Arabameri\& Sheikh (2015); 16=Gillham, Gillham\& Hansen (2015); 17=Howells \& Fletcher (2015);18=Martin et al. (2015);19=White \& Bennie (2015); 20= Brown, Lafferty \&Triggs (2015); 21=Cox et al. (2016); 22=Cuberos et al. (2016); 23=Lu et al. (2016); 24=Gabana (2016); 25=Gonzalez, Detling\&Galli (2016); 26=Nicholl, Morley\& Perry (2016); 27=Pedro (2016); 28=Tutte\&Reche (2016); 29=Garcia-Secades et al. (2016); 30=Ueno\& Suzuki (2016); 31=Bingol\&Bayansalduz(2016); 32= Sánchez et al. (2016); 33=Laborde, Guill\& Mosley (2016); 34= Meggs et al. (2016); 35= Cowden, Meyer-Weitz \& Asante (2016); 36= Cowden \& Meyer-Weitz (2016); 37= García-Secades, et al. (2017); 38=Ueno\&Oshio (2017); 39= Juarros et al (2018); 40=Ortega et al. (2017); 41=Deen, Turner, \& Wong (2017); 42= Prats, Ortega, \& González (2017); 43=Timm et al. (2017); 44=Fasczewski \& Gill (2017); 45=Pedro e Veloso (2018); 46=Reche et al. (2018); 47=Ortega, Fernández \&Extremera (2018

\section{Characteristics of the Sample of Athletes' in Resilience Studies}

Researchers often work with samples that include less than 25 athletes $(31.91 \%)$ of both sexes $(76.59 \%)$. The majority focus on athletes in the age group 17-23 years, whose careers are in ascension or at their peak $(29.23 \%)$. Few studies included athletes older than 27 years, which is often the final stage of their career $(12.30 \%)$.

Studies with samples based on mixed modalities (collective and individual sports) accounted for $46.80 \%$ of the total of the analyzed research. Studies with samples exclusively composed of individual sports accounted for $36.17 \%$ of the total number and collective sports accounted for $17.02 \%$ of the total. The majority of studies on resilience followed a crosssectional design (80.85\%) - and longitudinal studies accounted for $19.14 \%$.

Based on their design, research methods adopted in studies on athletes' resilience were $65.95 \%$ quantitative, $29.78 \%$ qualitative, and $4.25 \%$ were a mix of quantitative and qualitative. The most commonly used scale to assess resilience in athletes was the CD-RISC (Connor \& Davidson, 2003) - 25 and 10 -item versions -, which was applied in $24.99 \%$ of studies focused on assessing athletes' resilience; 


\section{Bicalho, C.C.F., Melo, G.F., \& Noce, F.}

followed by the Resilience Scale (Wagnild\& Young, 1993) (20.83\%).

Interviews were applied in $20.83 \%$ of the studies and other tools, such as the Ego Resilience Scale (Block \&Kremen, 1996), the Academic Resilience Scale (Martin \& Marsh, 2006), the Psychological Resilience Scale for University Athletes (Ueno \& Shimizu, 2012), the Resistence Peer Influence Scale (Steinberg \& Monahan, 2007), the Posttraumatic Growth Inventory (Tedeschi\& Calhoun,1996), the Psychological Well-Being Scale (Lindfors, Berntsson\& Lundberg, 2006; Ryff\& Keyes, 1995), and the Resilience Scale for Adults (Friborget al., 2003) were less frequently used in the studies (less than 4\%). Approximately $10 \%$ of studies in this field applied interventional therapies to identify or develop resilience in athletes.

Europe accounts for the largest number of publications (35.29\%), followed by North America (21.56\%), South America and Asia (13.72\%), Oceania (7.84 \%), and Africa $(5.88 \%)$. The largest number of publications on athletes' resilience was recorded between 2012 and 2018 (85.10\%). This number demonstrates how interest in this subject has increased in the last 5 years.

\section{Citation network analysis in athletes' resilience}

The network of the 47 articles presented 94 relationships between them. Mean network cohesion was 1.95 , which is the mean degree of article entry into and exit from the network. Connectivity between articles in the network reached $5 \%$. Net density rate was $4.2 \%$, and this number indicates greater dispersion among some articles. Density and connectivity were low in comparison to other studies (Miranda \& Borges, 2019; Gustafsson, Hancock \&Côté, 2014). The network recorded a fragmentation index of 0.942 , which was classified as good, since this indicates that, despite the absence of an article, this network remains consistent. Node 6 (Fletcher \& Sarkar, 2012) presented the most expressive centrality degree $(59.57 \%)$, followed by Node 1 (Galli\&Vealey, 2008) (42.55\%) and Node 10 (Morgan, Fletcher \& Sarkar, 2013) (21.27\%). Nodes representing articles $4,8,15,24,26,44$ were not connected to other articles in the network, they were isolated; therefore, they were listed outside the network (Figure 2).

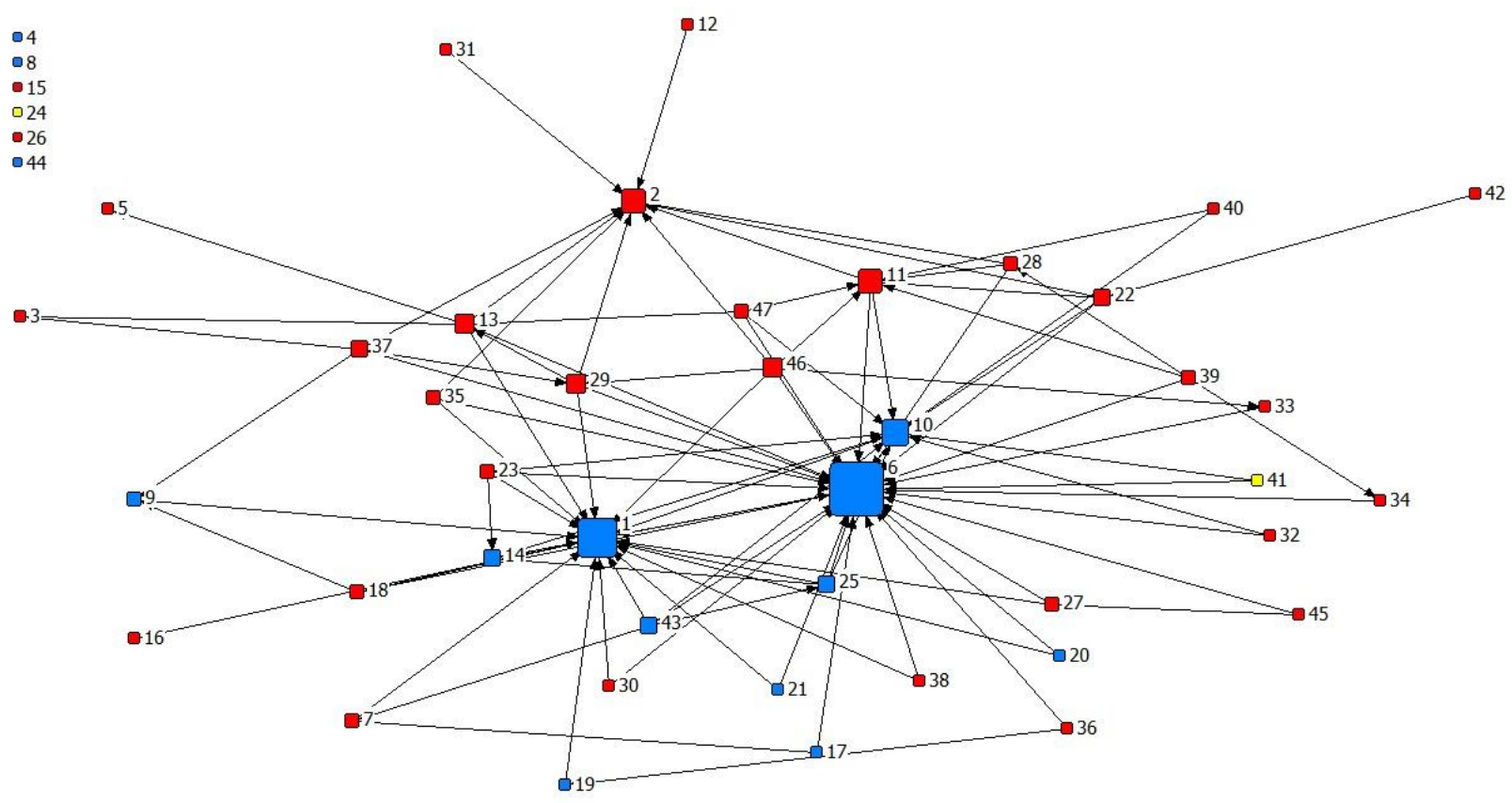

Cuadernos de Psicología del Deporte, 20, 3 (julio) 


\section{Resilience of athletes}

Figure 2: Visual representation of the citation analysis of research on athletes' resilience. Caption: blue node = qualitative studies; red node = quantitative study, yellow node = mixed method. Note: The five most referenced articles were: \#6 Fletcher \& Sarkar, 2012 (28 citations); \#1 Galli\&Vealey, 2008 (19 citations); \#10 Morgan, Fletcher, \& Sarkar, 2013 (12 citations); \#2 Hosseini\&Besharat, 2010 (9 citations), \#11 Garcia, Valarino, \& Monteiro, 2014 (9 citations).

\section{DISCUSSION}

The main aim of the present study was to understand the indicators and scope of theoretical models on athletes' resilience. It is interesting to note that articles focused on developing models to assess resilience in the sports context ranked in first and second positions (Galli\&Vealley, 2008 Node 1; Fletcher \& Sarkar, 2012 Node 6). This prominence indicates that the theoretical models produced by sport psychology are the most common in the published research studies on resilience in athletes.

Although the Conceptual Model of Resilience, by Galli and Vealey (2008), was a pioneering theory in sports psychology, it received criticism for disregarding the reflexive process of athletes. In addition, for some authors, the theory confuses the resilience reintegration process and coping strategies. According to Fletcher and Sarkar (2012), in the Conceptual Model of Sports Resilience athletes' coping strategies are biased, since this model assesses adverse situations as if they were actual problems rather than challenges; it does not take into consideration the athletes themselves to evaluate their own thoughts or the role played by emotions in the reintegration process.

The Grounded Theory of Psychological Resilience and Optimal Performance for Sport (Fletcher \& Sarkar, 2012) ensures that psychological resilience is therefore represented as a comprehensive concept that encapsulates stressors, cognitive assessment and metacognitions, psychological factors (positive personality, motivation , trust, focus, perceived social support), and facilitating responses. This model was better accepted by sports psychology researchers focused on understanding athletes' resilience, and was the study that registered the greatest centrality of the network. Furthermore, there is dominance of this model in the interpretation of the athlete's resilient behavior, since $85 \%$ of the studies are published after the year 2012 and more than $60 \%$ cite this study.
However, it is worth mentioning that resilience studies are still very recent. With respect to this field of study, there is still much to be explored and understood in the relationship of this construct with the sports performance and mental health of athletes. First, Bryan et al. (2018) defend the idea that, in addition to taking into account the adverse situations proposed in the model by Fletcher and Sarkar (2012), it is necessary to observe the type and magnitude of the effect of these adversities on the development of athletes' resilience. However, these statements are based on fairly recent data and clinical studies are needed to help better understand the interaction of stressors in the development of resilience. Second, according to Wagstaff et al. (2016), the influence of socio-cultural factors and context still needs to be further explored in this theoretical model, given its importance for the athletes' resilience.

With respect to the interconnectivity of studies, Morgan, Fletcher and Sarkar (2013) occupy the third position in the citation network. The authors understand the concept of resilience in team sports as a dynamic psychosocial process that protects a group of individuals from the potential negative effect of the stressors that they encounter collectively. It consists of processes by which team members use their individual and collective resources to adapt positively in the face of adversity. Overall, this definition suggests that the team's resilience characteristics are integrated into the dynamic psychosocial process considering five related characteristics, namely: transformational leadership, group structure, domain approaches, social capital, and collective effectiveness.

These new elements introduced by Morgan, Fletcher and Sarkar (2013) allowed better understanding of resilience features in collective sports and opened a new discussion about individual and collective sports (ChacónCuberos, Castro-Sanchez, Espejo-Garcés, et al., 2016; Morgan, Fletcher \& Sarkar, 2015; Prats, Zuita-Ortega, \& González, 2017). More recent studies have shown that athletes with higher resilience have 


\section{Bicalho, C.C.F., Melo, G.F., \& Noce, F.}

better chances of achieving good results when exposed to adverse situations (Machida, Irwin \&Feltx, 2013; Sánchez et al., 2016).

Some studies of the citation network sought to understand the relationship of resilience with other psychological constructs. It was observed that these studies are recent, the majority published in the last 5 years, and, yet, they are already influential in the literature of sport psychology. For example, athletes have individual components that help them deal with adverse situations in a positive way, observed in characteristics such as positivity, competitiveness, commitment, maturity, persistence, and passion for sport, among other components (Brown, Lafferty \&Triggs, 2015; Pedro, 2016; Sarkar \& Fletcher, 2014). Through these studies it is possible to state that motivation and focus on sporting achievements contribute to withstanding adverse situations and maintaining positive results, even in stressful situations.

The literature provides some directions, stating that more experienced athletes tend to be more resilient. Reche et al. (2018) found higher resilience scores in senior fencers; it is assumed that athletes'commitment and dedication have a stronger influence on resilience skills than age or sports category (Tutte\&Reche, 2016). However, research on the relationship between maturity and resilience remains inconclusive, advocating for the hypothesis that the environmental component is an independent variable that influences athletes' maturational development and, consequently, their resilience skills.

Among the studies in the citation network, those with samples of Parathletes demonstrate that these athletes seem to experience different resilience processes from other groups of athletes, and these processes should be better investigated (Cardoso \& Sacomori, 2014; Fasczewski\& Gill, 2017; Martin et al., 2015). Disabled athletes face many environmental (e.g. transportation, accessibility) and social barriers (e.g. prejudice and stigmatization) that have a negative influence on satisfaction with life. According to Martin et al. (2015), engagement of disabled individuals in sports can influence more active participation of other individuals; moreover, it can contribute to resilience development, as well as to better self-esteem and personal satisfaction with life. Nevertheless, paralympic sports are little studied; therefore, this field requires further investigations, since it is essential to understand the effects of resilience on parathletes' performance and quality of life.

Social support from coaches seems to be a variable capable of influencing the resilience profile of athletes (Gillham, Gillham\& Hansen, 2015; Lu et al., 2016; Pedro \&Veloso, 2018), as resilient athletes appear to be influenced by their peers (Fletcher \& Sarkar, 2012; Machida, Irwin \&Feltz, 2013; Nicholls, Morley \& Perry, 2016). These studies demonstrated that the athlete's resilience is associated with the feeling and perception of support for coaches 'autonomy, motivational guidance, and the coaches' ability to promote a team mentality. There is still much to be investigated about the influence of the trainer-athlete relationship and its impact on the development of athletes' resilience throughout their careers.

Understanding the development of resilience in female and male athletes is still unclear. Overall, studies focused on analyzing resilience in female and male athletes and did not identify differences between sexes (Bingol\&Bayansalduz, 2016, Boghrabadi, Arabameri\& Sheikh, 2015, Hosseni and Besharat, 2010). However, Galli and Reel (2012) observed that female athletes reported greater spiritual change and ability to relate to others than male athletes. Ortega et al. (2017) found that men can be more confident in their physical skills under higher motivational pressure, gaining more satisfaction from the task to be accomplished and, therefore, demonstrating more resilience than women. Nevertheless, the analyses carried out so far about athletes'performance are not sufficiently accurate to address resilience behavior based on sex.

Another important perspective of studies on resilience in athletes is the relationship with sports performance. This was perceived in the citations network analysis in the study of Hosseini and Besharat (2010), as the authors presented the greatest impact in European and South American studies. Based on the results, there is a positive correlation between resilience, sports performance, and psychological well-being, as well as a negative correlation between resilience and psychological distress; in addition, resilience may be associated with changes in athletic performance. 


\section{Resilience of athletes}

The hypothesis raised by Hosseini and Besharat (2010) is that levels of resilience are related to the increase in the levels of personal consistency, and reinforcement of personal consistency is related to the greater probability of achieving better sporting achievements and improvement in mental health. In the same way, Cevada et al. (2012) showed that more resilient athletes are better prepared to overcome the challenges and stress of sporting environments, a fact that increases the probability of having a successful career in sport

Based on the present literature review, quantitative studies recorded the greatest representativeness. However, qualitative studies could indicate more precise responses of athletes' resilience behaviors until a specific tool for this sports' construct is established. In addition, the lack of validated quantitative tools for sports makes it difficult to compare resilience between published studies, as well as between studies that relate resilience to other physiological variables such as cortisol use (Meggs, et al., 2016), burnout (Lu et al., 2016; Reche, Tutte\&Ortín, 2014; Tutte\&Reche, 2016; Ueno \& Suzuki, 2016), stress (García-Secades et al., 2017; Juarroset al., 2018; Lu et al., 2016; Meggset al., 2016), optimism (Reche, Tutte\&Ortín, 2014; Recheet al., 2018; Tutte\&Reche, 2016), anxiety (Cevadaet al., 2012; Ortega et al., 2018), well-being, and quality of life (Nezhad\&Besharat 2010; Cevadaet al., 2012; White \& Bennie, 2015). Interestingly, investigations of athletes'resilience are recent and there is no reliable quantitative tool in the literature to assess them.

This study has limitations to be considered. The study focused on two theoretical models published on resilience in athletes in the sport psychology literature, not covering the general psychology models. However, the sport resilience theory models were developed under the pillars of psychology theory (ex. Richardson, 1990; Rutter, 1987; 2000). In addition, studies that used this method also point out that the citation method is influenced by the year of publication of the article (Gustafsson et al. 2014), older articles have a greater likelihood of being cited as they have existed for longer than newer articles. Therefore, caution is recommended when interpreting the citation results. The results presented in this article provide an image that complements previous analyzes on sports resilience; this is a detailed analysis of the understanding of this construct in relation to athletes (Bryan, O'Shea and MacIntyre, 2017, Wagstaff et al. 2016).

\section{CONCLUSION}

In conclusion, the most influential model explaining sport resilience is Grounded Theory of Psychological Resilience and Optimal Sport Performance (Fletcher \& Sarkar, 2012) seems to encompass the elementary theoretical aspects to understand resilience in highperformance athletes to date. Based on the literature, resilience is an on-going dynamic process based on individual characteristics and on interactions with the environment.

Examining the results of the citation network analysis, its noted that sport resilience research demonstrated an appropriate amount of connectivity between articles and researchers. Within the network, a typical and highly cited article was quantitative, male and female athletes combined. Studies on resilience in sport are recent and have sought to understand the construct by observing the specific characteristics of sport and athletes. Additionally, the most cited papers were conducted by European researchers; however, researchers from North American, South American and Asia appear to be getting more attention recently.

\section{REFERENCES}

1. Belem, I.C., Caruzzo, N.M., Nascimento Jr, J.R.A.D., Vieira, J.L.L. \& Vieira, L.F. (2014). Impact of coping strategies on resilience of elite beach volleyball athletes. Revista Brasileira de Cineantropometria\& Desempenho Humano, 16(4), 447-455. https://doi.org/10.5007/19800037.2014v16n4p447

2. Bicalho, C.C.F \& Costa, V.T. (2018). Burnout in elite athletes: a systematic review. Cuadernos de Psicología del Deporte, 18(1),89-102, 2018.

3. Bingol, E. \& Bayansalduz, M. (2016). Evaluating the level of exercise dependence and psychological resilience of athletes from different branches. The Anthropologist, 24(3), 827835.https://doi.org/10.1080/09720073.2016.1189 2079

4. Block, J. \& Kremen, A.M. (1996). IQ and egoresiliency: conceptual and empirical connections 


\section{Bicalho, C.C.F., Melo, G.F., \& Noce, F.}

and separateness. Journal of Personality and Social Psychology, 70(2),349361.https://doi.org/10.1037/0022-3514.70.2.349

5. Boghrabadi, S.G., Arabameri, E.\&Sheikh, M.A. A. (2015). Comparative Study on Resiliency and Stress Coping Strategies among Individual and Team Elite Athletes and Non-Athletes. International Journal of Review in Life Sciences, 5(3), 566-572.

6. Borgatti, S.P. (2002). NetDraw: Graph Visualization Software. Harvard: Analytic Technologies

7. Borgatti, S.P. \& Everett, M.G.; Johnson, J.C. Analyzing Social Networks. SagePublications, 2013. Disponível em $<$ http://faculty.ucr.edu/ hanneman/nettext/>.

8. Borgatti, S.P., Everett, M.G \& Freeman, L.C. (2002).Ucinet 6 for Windows: Software for Social Network Analysis. Harvard, MA: Analytic Technologies.

9. Brown, H.E., Lafferty, M.E. \& Triggs, C. (2015). In the face of adversity: Resiliency in winter sport athletes. Science \& Sports, 30(5), 105117.https://doi.org/10.1016/j.scispo.2014.09.006.

10. Bruner, M., Eys, M.A., Beauchamp, M.R. \& Côté, J. (2013).Examining the origins of team building in sport: a citation network and genealogical approach. Group Dynamics: Theory, Research, and Practice, 17,3042.https://doi.org/10.1037/a0030114.

11. Bryan, C., O'shea, D. \& Macintyre, T.E. (2018). The what, how, where and when of resilience as a dynamic, episodic, self-regulating system: A response to Hill et al. Sport, Exercise \& Performance Psychology, 7(4), 355362.https://doi.org/10.1037/spy0000133

12. Bryan, C., O'Shea, D., \&MacIntyre, T. (2017). Stressing the relevance of resilience: A systematic review of resilience across the domains of sport and work. International Review of Sport and Exercise Psychology, 141.https://doi.org/10.1080/1750984X.2017.13811 40

13. Cardoso, F.L.\& Sacomori, C. (2014). Resilience of athletes with physical disabilities: A cross- sectional study. Revista de Psicologia del Deporte, 23(1), 15-22.

14. Cevada, T., Cerqueira, L.S., Moraes, H.S, Santos, T.M., Pompeu, F.A.M.S. \& Deslandes, A.C. (2012). Relação entre esporte, resiliência, qualidade de vida e ansiedade. Revista Psiquiatria Clínica, 39(3), 8589.https://doi.org/10.1590/S0101608320120003000

15. Connor, K.M. \& Davidson, J.R. (2003). Development of a new resilience scale: the Connor-Davidson Resilience Scale (CD-RISC). Depress and Anxiety, 18(2), 7682.https://doi.org/10.1002/da.10113

16. Cowden, R.G. \& Meyer-Weitz, A. (2016). Selfreflection and self-insight predict resilience and stress in competitive tennis. Social Behavior and Personality: an International Journal, 44(7), 11331149.https://doi.org/10.2224/sbp.2016.44.7.1133

17. Cowden, R.G. \& Meyer-Weitz, A.; Asante, K.O. (2016). Mental toughness in competitive tennis: relationships with resilience and stress. Frontiers in Psychology, 320. https://doi.org/10.3389/fpsyg.2016.00320

18. Cox, H., Neil, R., Oliver, J. \& Hanton, S. (2016). PasSport4life: A trainee sport psychologist's perspective on developing a resilience-based life skills program. Journal of Sport Psychology in Action, 7(3), 182192.https://doi.org/10.1080/21520704.2016.1240 733

19. Cuberos, R.C., Sánchez, M.C., Garcés, T.E, \& Ortega, F.Z. (2016). Estudio de la resiliência en función de la modalidad deportiva: fútbol, balonmano y esquí. RETOS. Nuevas Tendencias en Educación Física, Deporte y Recreación, 29, 157-161.

20. Deen, S., Turner, M.J. \& Wong, R.S. (2017). The effects of REBT, and the use of credos, on irrational beliefs and resilience qualities in athletes. The Sport Psychologist, 31(3), 249263.https://doi.org/10.1123/tsp.2016-0057

21. Fasczewski, K. \& Gill, D. (2017). Case study of a female competitive mountain bike racer with multiple sclerosis. Case Studies in Sport and Exercise Psychology, 1(1), 94102.https://doi.org/10.1123/cssep.2017-0002 


\section{Resilience of athletes}

22. Fletcher, D. \& Sarkar, M. (2012). A grounded theory of psychological resilience in Olympic champions. Psychology of Sport and Exercise, 13,669

678.https://doi.org/10.1016/j.psychsport.2012.04. 007

23. Fletcher, D. \& Sarkar, M. (2013). Psychological resilience: A review and critique of definitions, concepts and theory. European Psychologist, 18, 12-23.https://doi.org/10.1027/10169040/a000124

24. Fontes, R.C.C. \& Brandão, M.R.F. (2013).A resiliência no âmbito esportivo: uma perspectiva bioecológica do desenvolvimento humano. Motriz, 19(1), 151159.https://doi.org/10.1590/S198065742013000100015

25. Friborg, O., Hjemdal, O., Rosenvinge, J.H. \& Martinussen, M. (2003). A new rating scale for adult resilience: what are the central protective resources behind healthy adjustment? International Journal of Methods in Psychiatric Research, 2(2), 6576.https://doi.org/10.1002/mpr.143

26. Gabana, N. (2016). A strengths-based cognitive behavioral approach to treating depression and building resilience in collegiate athletics: the individuation of an identical twin. Case Studies in Sport and Exercise Psychology, 1(1), 415.https://doi.org/10.1123/cssep.2016-0005

27. Galli, N. \& Gonzalez, S.P. (2014). Psychological resilience in sport: A review of the literature and implications for research and practice. International Journal of Sport and Exercise Psychology, 13(3), 243257.https://doi.org/10.1080/1612197X.2014.9469 47

28. Galli, N. \& Reel, J.J. (2012). Can good come from bad? An examination of adversarial growth in Division I NCAA athletes. Journal of Intercollegiate Sport, 5(2), 199212.https://doi.org/10.1123/jis.5.2.199.

29. Galli, N. \& Vealey, R. (2008). Bouncing back from adversity: Athletes' experiences of resilience. The Sport Psychologist, 22, 316335.https://doi.org/10.1123/tsp.22.3.316
30. García, C. R., Vallerino, V. T., \& Montero, F. J. O. (2014). Resilencia, optimismo y burnour en judokas de competición uruguayos. Revista Iberoamericana de Psicología del Ejercicio Y El Deporte, 9(2), 271-286.

31. García-Secades, X., Molinero, O., Salguero, A., Ruíz R.B., De La Vega, R.\&Márquez, S. (2016). Relationship between resilience and coping strategies in competitive sport. Perceptual and Motor Skills, 122(1), 336349.https://doi.org/10.1177/0031512516631056

32. García-Secades, X.; Molinero, O.; Ruíz R.B.; Salguero, A.; De La Vega, R.; Márquez, S. (2017).Resiliência y recuperación-estrés en deportistas de competición. Cuadernos de Psicologíadel Deporte, 17(2), 73-80.

33. Gillham, A., Gillham, E. \& Hansen, K. (2015). Relationships among coaching success, servant leadership, cohesion, resilience and social behaviors. International Sport Coaching Journal, 2(3), 233-247.https://doi.org/10.1123/iscj.20140064

34. Gonzalez S.P.,Moore, E.W.G.,Newton, M.\&Galli, N.A. (2016). Validity and reliability of the Connor-Davidson Resilience Scale (CDRISC) in competitive sport. Psychology of Sport and Exercise, 23, 3139.https://doi.org/10.1016/j.psychsport.2015.10.0 05

35. Gonzalez, S.P.,Detling, N.\&Galli, N. A.(2016). Case studies of developing resilience in elite sport: applying theory to guide interventions. Journal of Sport Psychology in Action, 7(3), 158169.https://doi.org/10.1080/21520704.2016.1236 050

36. Goodger, K.,Gorely, T.,Lavallee, D. \&Harwood, C. (2007). Burnout in sport: A systematic review. The Sport Psychologist,21(2), 127151.https://doi.org/10.1123/tsp.21.2.127

37. Gucciardi, D.F.,Jackson, B.,Coulter, T.J.\&Mallett, C.J. (2011). The Connor-Davidson Resilience Scale (CD-RISC): Dimensionality and age-related measurement invariance with Australian cricketers. Psychology of Sport \& Exercise, 12, 423433.https://doi.org/10.1016/j.psychsport.2011.02. 005 


\section{Bicalho, C.C.F., Melo, G.F., \& Noce, F.}

38. Gustafsson, H.,Hancock, D. J.\&Côté, J. (2014). Describing citation structures in sport burnout literature: A citation network analysis. Psychology of Sport and Exercise, 15(6), 620626.https://doi.org/10.1016/j.psychsport.2014.07. 001

39. Holt, N.L.\&Dunn, J.GH. (2004). Toward a grounded theory of the psychosocial competencies and environmental conditions associated with soccer success. Journal of Applied Sport Psychology, 16(3), 199219.https://doi.org/10.1080/10413200490437949

40. Hosseini, S.A. \&Besharat, M.A. (2010). Relation of resilience whit sport achievement and mental health in a sample of athletes. Procedia-Social and Behavioral Sciences, 5, 633638.https://doi.org/10.1016/j.sbspro.2010.07.156

41. Howells, K.\&Fletcher, D. (2015). Sink or swim: adversity-and growth-related experiences in Olympic swimming champions. Psychology of Sport and Exercise, 16, 3748.https://doi.org/10.1016/j.psychsport.2014.08.0 04

42. Juarros, M.A.,Del Valle, A.S.,González, O.M.,Rosado, A.F.B.,Rosa, S.M. (2018). Relación de la carga interna de entrenamiento, optimismo y resiliência con los niveles de estrésrecuperación en nadadores. Cuadernos de Psicología del Deporte, 18(1), 43-54.

43. Laborde, S.,Guillén, F.,Mosley, E. (2016).Positive personality-trait-like individual differences in athletes from individual-and team sports and in non-athletes. Psychology of Sport and Exercise, 26, 913.https://doi.org/10.1016/j.psychsport.2016.05.0 09

44. Lindfors, P.,Berntsson, L. \&Lundberg, U. (2006). Factor structure of Ryff's psychological wellbeing scales in Swedish female and male whitecollar workers. Personality and Individual Differences, 40(6), 12131222.https://doi.org/10.1016/j.paid.2005.10.016

45. Lu, F.J.,Lee, W.P.,Chang, Y.K.,Chou, C.C., Hsu, Y.W.,Lin, J.H.\&Gill, D. L. (2016) Interaction of athletes' resilience and coaches' social support on the stress-burnout relationship: A conjunctive moderation perspective. Psychology of Sport and
Exercise,

22 ,

$202-$

209.https://doi.org/10.1016/j.psychsport.2015.08. 005

46. Luthar, S.S.\&Cicchetti, D. (2000).The construct of resilience: Implications for interventions and social policies. Development and Psychopathology, 12(4), 857885.https://doi.org/10.1017/S0954579400004156

47. Luthar, S.S.,Cicchetti, D.\&Becker, B. (2000). The construct of resilience: A critical evaluation and guidelines for future work. Child Development, 71(3), 543-562.https://doi.org/10.1111/14678624.00164

48. Machida, M.,Irwin, B.\&Feltz, D. (2013). Resilience in competitive athletes with spinal cord injury: the role of sport participation. Qualitative Health Research, 23(8), 10541065.https://doi.org/10.1177/1049732313493673

49. Martin, A.J.\&Marsh, H.W. (2006). Academic resilience and its psychological and educational correlates: A construct validity approach. Psychology in the Schools, 43, 267282.https://doi.org/10.1002/pits.20149

50. Martin, J.J.,Byrd, B.,Watts, M.L.\&Dent, M. (2015). Gritty, hardy, and resilient: predictors of sport engagement and life satisfaction in wheelchair basketball players. Journal of Clinical Sport Psychology, 9(4), 345359.https://doi.org/10.1123/jcsp.2015-0015

51. Masten, A.S. (2001). Ordinary magic: Resilience processes in development. American Psychologist, 56(3), 227238.https://doi.org/10.1037/0003-066X.56.3.227

52. Meggs, J.,Golby, J.,Mallett, C., Gucciardi, D.\&Polman, R. (2016). The cortisol awakening response and resilience in elite swimmers. International Journal of Sports Medicine, 37(2), 169-174.https://doi.org/10.1055/s-0035-1559773

53. Mills, A.,Butt, J.,Maynard, I.\&Harwood, C. (2012). Identifying factors perceived to influence the development of elite youth football academy players. Journal of Sports Sciences, 30(15), 15931604.https://doi.org/10.1080/02640414.2012.710 753

54. Miranda M.G.\&Borges R. (2019). Technologybased business incubators: An exploratory 


\section{Resilience of athletes}

analysis of intra-organizational social networks. Innovation \& Management Review, 16(1), 3654.https://doi.org/10.1108/INMR-04-2018-0017

55. Morgan, P.B.,Fletcher, D.\&Sarkar, M. (2013). Defining and characterizing team resilience in elite sport. Psychology of Sport and Exercise, 14, (4), $549-$ 559.https://doi.org/10.1016/j.psychsport.2013.01. 004

56. Morgan, P.B.,Fletcher, D.\&Sarkar, M. (2015). Understanding team resilience in the world's best athletes: A case study of a rugby union World Cup winning team. Psychology of Sport and Exercise, 16 , 91100.https://doi.org/10.1016/j.psychsport.2014.08. 007

57. Nezhad, M.A.S.; Besharat, M.A. (2010). Relations of resilience and hardiness with sport achievement and mental health in a sample of athletes. Procedia-Social and Behavioral Sciences, $\quad 5$, 757763.https://doi.org/10.1016/j.sbspro.2010.07.180

58. Nicholls, A.R.,Morley, D.,Perry, J.L. (2016). The model of motivational dynamics in sport: Resistance to peer influence, behavioral engagement and disaffection, dispositional coping, and resilience. Frontiers in Psychology, 6. https://doi.org/10.3389/fpsyg.2015.02010

59. Ortega, F.Z.,Fernández, S.R.,Extremera, M.O.,Sánchez, M.C., Cuberos, R.C.\&González, M.C. (2018). Análisis de la resiliência, ansiedad y lesión deportiva en fútbol según el nivel competitivo. Cultura, Ciencia, Deporte, 12(35), 135-42.https://doi.org/10.12800/ccd.v12i35.885

60. Ortega, F.Z.,Santos, E.O.Z., Moral, P.V.,Fernández, S.R.,Sánchez, M.C.\&Molina, J.J.M. (2017). Análisis de la resiliência,autoconcepto y motivación en judo según el género. Revista de PsicologíadelDeporte, 26(1), 71-81.

61. Pedro, S. D. (2016). Athletes Engagement, Resilience, and Rate of Perceived Exertion on Portuguese National-and International-Level Wrestlers. International Journal of Wrestling Science, 6(1), 5-10. https://doi.org/10.1080/21615667.2016.1166299
62. Pedro, S.D.\&Veloso, S. (2018). Explorando la resiliência en deporte. Apoyo del entrenador a la autonomía y compromiso del Atleta-Una contribución a la literatura. Cuadernos de Psicología del Deporte, 18(1), 151-160.

63. Prats, S.B.,Ortega, F.Z.,González, M.C. (2017). Análisis de los constructos de autoconcepto y resiliência, en jugadoras de baloncesto de categoría cadete. Revista de Psicología del Deporte, 26(1), 127-132.

64. Reche, C.,Gómez-Díaz, M.,Martínez-Rodríguez, A.\&Tutte, V. (2018). El optimismo como contribución a la resiliênciadeportiva. Revista Iberoamericana de Psicología del Ejercicio y el Deporte,13(1), 131-36.

65. Richardson, G.E.,Neiger, B.L.,Jensen, S.,Kumpfer, K.L. (1990). The resiliency model. Health Education, 21, p.33-9. https://doi.org/10.1080/00970050.1990.1061458 9

66. Rutter, M. (1987). Psychosocial resilience and protective mechanisms. AmericanJournal of Orthopsychiatry, $57, \quad 316 \mathrm{e} 331$. doi:10.1111/j.1939-0025.1987.tb03541.x.

67. Rutter, M. (2000). Resilience reconsidered: conceptual considerations, empiricalfindings, and policy implications. In J. P. Shonkoff, \& S. J. Meisels (Eds.), Handbook of early childhood intervention (pp. 651e682). New York: Cambridge University Press

68. Ryff, C.D.\&Keyes, C.L.M. (1995). The structure of psychological well-being revisited. Journal of Personality and Social Psychology, 69(4), p.71927. https://doi.org/10.1037/0022-3514.69.4.719

69. SallisJ.F.,ProchaskaJ.J.\&Taylor, A.C. (2000). A review of correlates of physical activity of children and adolescents. Medicine and Science in Sports and Exercise, 32, 963-75. https://doi.org/10.1097/00005768-20000500000014

70. Sanches, S.M.\&Rubio, K. (2011). A prática esportiva como ferramenta educacional: trabalhando valores e a resiliência. Educação e Pesquisa, 37(4), 825-42. https://doi.org/10.1590/S151797022011000400010 


\section{Bicalho, C.C.F., Melo, G.F., \& Noce, F.}

71. Sarkar, M. \& Fletcher, D. (2014). Ordinary magic, extraordinary performance: Psychological resilience and thriving in high achievers. Sport, Exercise, and Performance Psychology, 3(1), 46.https://doi.org/10.1037/spy0000003

72. Skinner, E.A.\&Pitzer, J.R. (2012). Developmental dynamics of student engagement, coping, and everyday resilience. In: Handbook of research on student engagement. Springer, Boston, MA. p. 2144.https://doi.org/10.1007/978-1-4614-2018-7_2

73. Steinberg, L.\&Monahan, K.C. (2007). Age differences in resistance to peer influence. Developmental Psychology, 43(6), 1531-43. https://doi.org/10.1037/0012-1649.43.6.1531

74. Tedeschi, R.G.\&Calhoun, L.G. (1996). The Posttraumatic Growth Inventory: Measuring the positive legacy of trauma. Journal of Traumatic Stress, 9(3), 455-71. https://doi.org/10.1002/jts.2490090305

75. Timm, K., Kamphoff, C., Galli, N.\&Gonzalez, S.P. (2017). Resilience and Growth in Marathon Runners in the Aftermath of the 2013 Boston Marathon Bombings. The Sport Psychologist, 31(1), 42-55.https://doi.org/10.1123/tsp.20150053

76. Tutte, V. \&Reche, C. (2016).Burnout, resiliência y optimismo en el hockey sobre hierba femenino. Cuadernos de psicología del deporte, 16(3), 73-8.

77. Ueno, Y.\&Oshio, A. (2017). Formation of resilience in Japanese athletes: Relevance to personality traits and day-to-day resilience. Journal of Physical Education and Sport, 17(3), 2030-33.

78. Ueno, Y.\&Shimizu, Y. (2012). Development of psychological resilience scale for university athletes. Japanese Journal of Sports Psychiatry, 9, 68-85. (in Japanese)

79. Ueno, Y. \&Suzuki, T. (2016). Longitudinal study on the relationship between resilience and burnout among Japanese athletes. Journal of Physical Education and Sport, 16(4), 1137-41.

80. Van Yperen, N.W. (2009). Why some make it and others do not: Identifying psychological factors that predict career success in professional adult soccer. The Sport Psychologist, 23(3), 31729.https://doi.org/10.1123/tsp.23.3.317
81. Wagstaff, C. R. D., Sarkar, M., Davidson, C. L., \& Fletcher, D. (2016). Resilience in sport: a critical review of psychological processes, sociocultural influences, and organizational dynamics. In The Organizational Psychology of Sport (p.120-149). Routledge.https://doi.org/10.4324/978131566653 2

82. Wagnild, G.M.\&Young, H.M. (1993). Development and psychometric evaluation of the Resilience Scale. Journal of Nursing Measurement, 1(2), 165-178.

83. White, R.L. \&Bennie, A. (2015). Resilience in youth sport: A qualitative investigation of gymnastics coach and athlete perceptions. International Journal of Sports Science \& Coaching, 10(2-3), 37993.https://doi.org/10.1260/1747-9541.10.2-3.379 